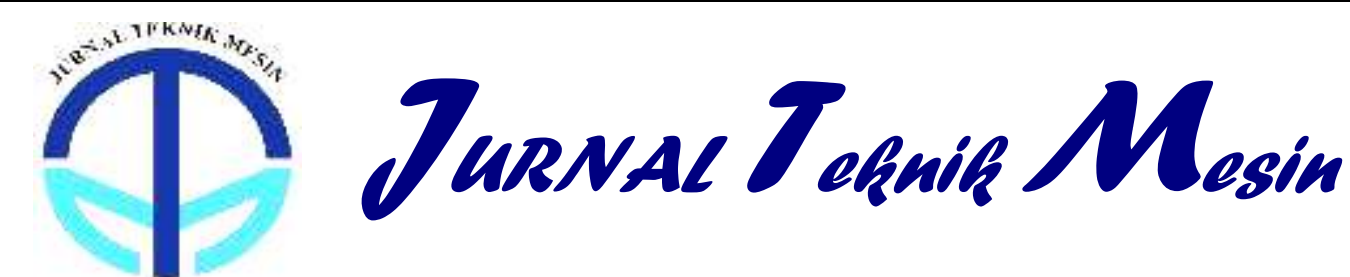

\title{
Pengaruh Fraksi Volume Serat Jerami Terhadap Kekuatan Material Komposit Aplikasi Kayu Lapis
}

\author{
Anggrek Otaviameta ${ }^{1}$, Kardiman $^{2}$, Farradina Choria Suci ${ }^{3}$ \\ ${ }^{123}$ Teknik Mesin, Fakultas Teknik, Universitas Singaperbangsa Karawang \\ ${ }^{1} 1710631150041 @$ student.unsika.ac.id ${ }^{2}$ kardiman@ft.unsika.ac.id ${ }^{3}$ farradina.cs@ft.unsika.ac.id
}

\begin{abstract}
Polymer Matrix Composite (PMC) is a composite material that uses a polymer matrix most widely used in industry, transportation, and everyday life. Plywood is one of the current industrial needs which is growing rapidly and is becoming a leading export. However, besides that, the availability of raw materials is decreasing along with deforestation. Resulting in the need for alternative raw materials. Straw is one of the largest wastes that is not utilized optimally. It can be straw as an environmentally friendly composite reinforcement material. This research was conducted to obtain an alternative raw material for plywood and to determine the effect of the volume fraction of straw fiber. Composite material was made using the hand lay up method, with straw fiber treated with $4 \% \mathrm{NaOH}$ using Yukalac 157 BQTN-EX unsaturated polyester resin and MEPOXE A hardener. Then, the test was carried out with volume fractions of straw fiber 5\%, 10\% 20\% and 30\% From this research, it can be concluded that the composite material with straw fiber and polyester matrix can be used as an alternative material for making plywood. The tensile strength values are $9.67 \mathrm{MPa}, 6.38 \mathrm{MPa}, 5.81 \mathrm{MPa}$, and $6.45 \mathrm{MPa}$, respectively. This shows that the volume fraction of straw fiber affects the strength of the composite material, with the tensile strength value of the fiber composite meeting the minimum tensile strength standard for plywood of 0.4 MPa. All samples met the minimum standard, but it can be seen from the surface structure that there were the most bubbles or voids in the 2 nd \& 3 rd samples with a fraction of $10 \%$ and $20 \%$. For this reason, it is necessary to try to minimize voids so that what occurs between the fiber and the matrix is perfect.Keywords: Straw fiber, composite, polyester, hand lay up, plywood.
\end{abstract}

\begin{abstract}
Abstrak
Polymer Matrix Composite (PMC) merupakan material komposit yang menggunakan matriks polimer paling banyak digunakan pada industri, transportasi, serta kehidupan sehari-hari. Kayu Lapis adalah salah satu kebutuhan industri saat ini yang berkembang pesat dan menjadi ekspor unggulan. Namun, disamping itu kesediaan bahan baku yang semakin menurun seiring terjadinya deforestasi, mengakibatkan perlunya bahan baku alternatifnya. Jerami adalah salah satu limbah terbesar yang pemanfaatannya kurang maskimal. Hal ini dapat menjadi jerami sebagai bahan penguat material komposit yang ramah lingkungan. Penelitian ini dilakukan guna mendapatkan bahan baku alternatif kayu lapis serta mengetahui pengaruh fraksi volume serat jerami. Dibuat material komposit dengan metode hand lay up, dengan serat jerami diberi perlakuan $\mathrm{NaOH} 4 \%$ dengan menggunakan resin polyester unsaturated Yukalac 157 BQTN-EX dan hardener MEPOXE A. Selanjutnya dilakukan pengujian tarik dengan fraksi volume serat jerami 5\%, 10\% 20\% dan 30\% Dari penelitian ini dapat disumpulkan bahwa material komposit berserat jerami dan bermatriks polyester dapat dijadikan bahan alternatif pembuatan kayu lapis. Dengan nilai kekuatan tarik masing-masing 9.67 MPa, 6.38 MPa, 5.81 MPa, dan 6.45 MPa. Hal ini menunjukkan fraksi volume serat jerami mempengaruhi kekuatan material komposit dengan, nilai kekuatan tarik komposit serat jerami memenuhi standar minimal kekuatan tarik pada kayu lapis sebesar 0,4 MPa. Semua sampel memenuhi standar minimal, tetapi dapat dilihat dari struktur permukaannya bahwa adanya gelembung atau void paling banyak pada sampel ke 2 \& 3 yang berfraksi $10 \%$ serta $20 \%$. Untuk itu perlu diusahakan meminimalisir void agar ikatan yan terjadi antara serat dan matriks terjadi sempurna.
\end{abstract}

Kata kunci: Serat jerami, komposit, polyester, hand lay up, kayu lapis.

\section{Pendahuluan}

Salah satu kebutuhan pada industri saat ini ialah kayu lapis. Dimana industri kayu lapis berkembang pesat, dan menjadi ekspor unggulan dalam sektor kehutanan, namun disamping itu pula kesediaan bahan baku yang semakin menurun seiring terjadinya deforestasi [1]. Sehingga di perlukan alternatif bahan baku untuk kayu lapis, mengingat banyak Sumber Daya Alam yang pemanfaatanya kurang.

Komposit adalah jenis bahan baru hasil rekayasa yang merupakan campuran dua atau lebih bahan dimana sifat masing-masing bahan berbeda baik sifat fisik maupun sifat kimia dan tetap terpisah walaupun sudah menjadi produk baru [2]. Polymer Matrix Composite 
(PMC) merupakan material komposit yang menggunakan matriks polimer paling banyak digunakan pada industri, transportasi serta kehidupan sehari-hari. Hal ini terjadi karena PMC memiliki sifat yang lebih ringan dan tahan terhadap korosi. PMC juga termasuk salah satu Material High Energy Absobing [3].

Dalam pembuatan material komposit terdiri atas matriks sebagai pengikat dan penguat berupa serat atau partikel. Serat yang digunakan di dunia industri umumnya serat sintetis yang sering digunakan sebagai matrial penguat seperti boron, karbon, E-Glass dsb [2]. Serat sintetis tersebut sulit terurai secara alami sehingga menyebabkan pencemaran lingkungan. Selain serat sistetis ada juga serat alam yang mudah di temukan di lingkungan sekitar. Serat alam yang sering digunakan pada pembuatan material komposit adalah serat pelepah pisang, aren, batang pisang, daun pisang, rami, ijuk dan lainnya [4].

Jerami merupakan salah satu limbah terbesar yang pemanfaatnnya tidak maksimal [5]. Limbah-limbah tersebut jumlahnya banyak serta lebih ramah lingkungan juga mampu terdegradasi alami. Hal ini mampu menjadikan serat jerami dijadikan bahan penguat material komposit Namun, serat jerami biasanya memiliki ukuran serat beragam, yang mempengaruhi kekuatan tariknya. Panjang serat jerami mempengaruhi kekuatan tarik pada material, memungkinkan terjadinya ikatan antar molekul yan baik penguat maupun matriks [6].

Serat jerami perlu diberi perlakuan alkali. Perlakuan alkali yang sering digunakan ialah $\mathrm{NaOH}$, karena lebih ekonomis. Perlakuan $\mathrm{NaOH}$ bertujuan untuk melarutkan lapisan yang menyerupai lilin di permukaan serat, seperti lignin, hemiselulosa, dan kotoran lainnya [7]. $\mathrm{NaOH}$ yang digunakan tidak lebih dari dari $5 \%$ (berat). Kadar 5\% mudah untuk dilunakkan sehingga tidak akan merusak serat dan lingkungan. Apabila kadar $\mathrm{NaOH}$ lebih dari 5\% mengakibatkan serat mudah putus dan rapuh [8].

Matriks pada komposit mempunyai bagian terbesar (dominan). Pada material komposit matriks memberikan pengaruh yang besar dalam mengikat material penguat selain berfungsi untuk mendistribusikan beban dan memberikan perlindungann dari pengaruh lingkungan. Matriks sendiri berfungsi untuk membentuk ikatan koheren, mendistribusikan tegangan, melindungi serat, penyumbang beberapa sifat seperti kekakuan, ketangguhan dan tahana listrik [2].

Proses produksi dari material komposit terdiri atas du acara, yaitu proses cetakan terbuka (open mould process) dan proses cetakan tertutup (closed mould process). Contact moulding atau hand lay up merupakan metode yang paling sederhana dan termasuk dalam metode terbuka dari proses produksi material komposit. Proses dari metode ini dengan cara menuangkan resin ke dalam serat yang berbentuk anyaman, rajuan atau yang lainnya. Kemudian diberi tekanan serta diratakan dengan rol atau kuas yang prosesnya dilakukan secara berulang hingga ketebalan yang diinginkan terpenuhi. Proses ini biasanya dilakukan pada temperatur suhu kamar. Kelebihan menggunakan metode ini adalah mudah dilakukan, cocok digunakan oleh komponen yang besar dan mempunyai volume rendah [2].

Sebelumnya telah dilakukan beberapa penelitian mengenai material komposit dengan serat jerami dimana, peningkatan fraksi volume mempengaruhi kekuatan mekanik [9],[10], panjang serat jerami mempengaruhi kekuatan material komposit [6], dan masa filler pada komposit serat jerami berpengaruh terhadap nilai tegangan tarik [11],

Penelitian ini dilakukan bertujuan untuk mengetahui pengaruh fraksi volume pada material komposit serat jerami yang pengaplikasiannya untuk kayu lapis. Lalu menyesuaikan kekuatan material komposit dengan standar SNI kayu lapis yang ada yang nilai kekuatan tariknya tidak kurang dari $0,4 \mathrm{MPa}$.

\section{Metode Penelitian}

Penelitian ini dilakukan di 2 tempat, yaitu di Lab Produksi Universitas Singaperbangsa Karawang untuk persiapan sampel dan di Lab Produksi Institut Teknologi Bandung untuk pengujian tarik. Penelitian ini dilakukan \pm 2 bulan dari persiapan, pengerjaan, pengujian dan pengolahan data. Penelitian dilakukan secara sistematis seperti ditunjukkan pada Gambar 1 flowchart metodologi penelitian.

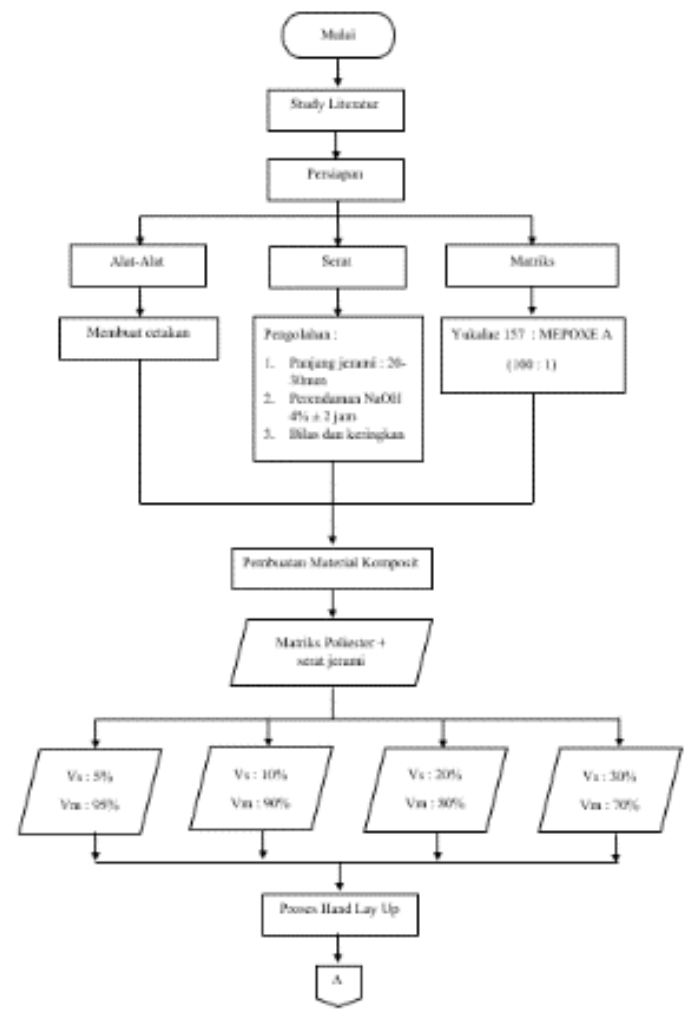




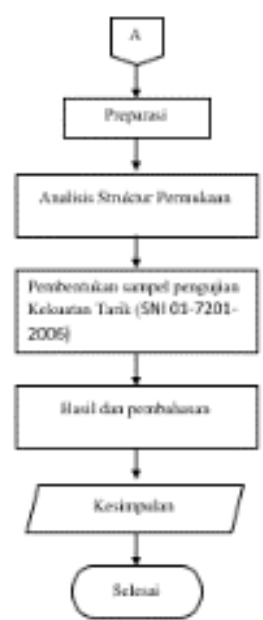

Gambar 1. Flowchart Metodologi Penelitian

\subsection{Studi Literatur}

Pembuatan material komposit dimulai dengan melakukan studi literatur. Studi literatur meliputi mengamati pengaplikasian material komposit yang telah ada serta mereview jurnal-jurnal terkait pembuatan material komposit sebelumnya. Terdapat banyak pengaplikasian, variasi serat, matriks, volume dll.

\subsection{Persiapan}

\subsubsection{Alat-alat}

Pembuatan material komposit ini hanya menggunakan alat-alat sederhana seperti pada Gambar 2.
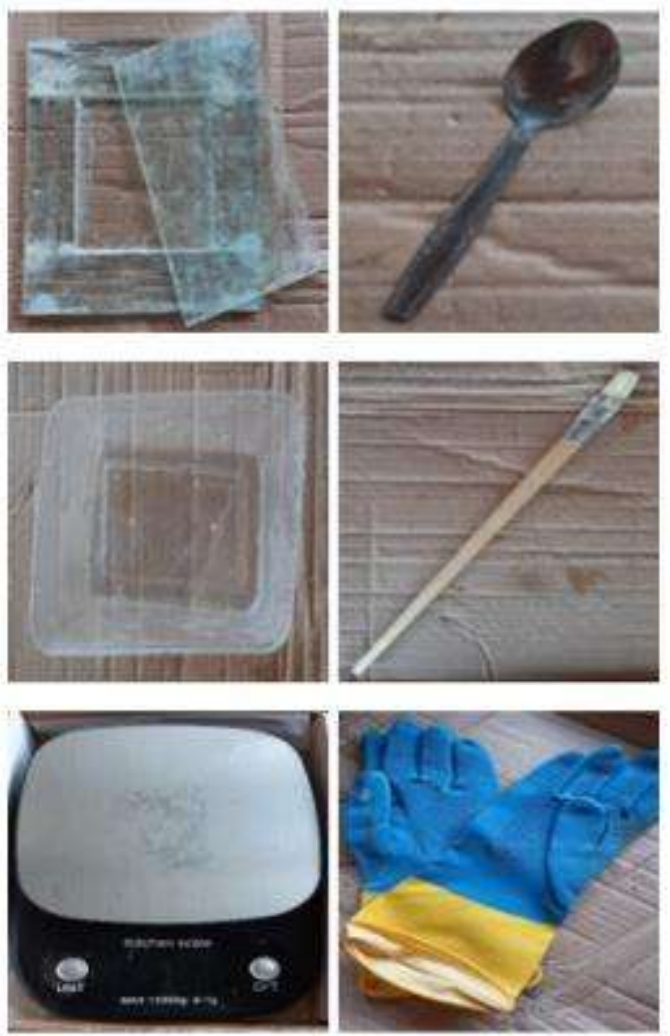

Gambar 2. Alat yang digunakan (cetakan, wadah, timbangan digital, sendok, kuas dan sarung tangan)

\subsubsection{Serat}

Pada penelitian ini digunakan serat jerami. Jerami yang sisa-sisa pasca panen dikumpulkan lalu dipotong-potong sepanjang $20-30 \mathrm{~mm}$ seperti pada Gambar 3. Selanjutnya jerami dibersihkan dengan air yang mengalir lalu diberi perlakuan $\mathrm{NaOH} 4 \%$ dalam sebuah wadah dan direndam selama \pm 2 jam. Setelah itu di bilas dan dikeringkan.

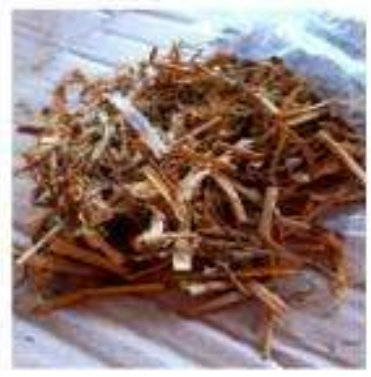

Gambar 3. Serat Jerami

\subsubsection{Matriks}

Penelitian ini menggunakan resin polyester sebagai matriks. Resin yang digunakan resin unsaturated polyester Yukalac 157 BQTN-EX dan hardener MEPOXE A produksi PT. Justus Kimiaraya seperti pada Gambar 4 dan Gambar 5. Lalu resin dan hardener dicampur dengan perbandingan 100:1 (berat) dalam wadah pencampur dan diaduk hingga homogen

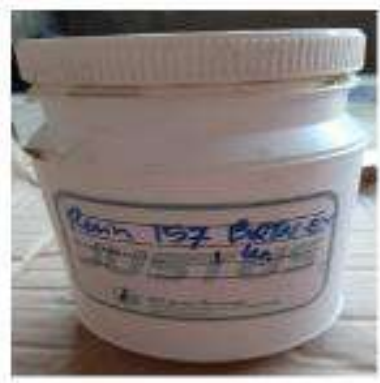

Gambar 4. Yukalac 157 BQTN-EX (PT. Justus Kimiaraya)

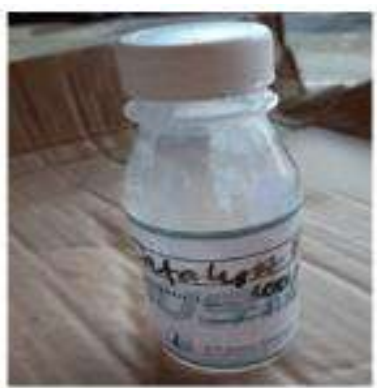

Gambar 5. MEPOXE A (PT. Justus Kimiaraya)

\subsection{Pembuatan Material Komposit}

Pembuatan material komposit dilakukan dengan metode hand lay up. Siapkan cetakan dengan diolesi dengan wax realese agent guna memudahkan pengambilan sampel dari cetakan. Serat dan matriks masukan ke dalam cetakan kemudian ditekan dengan penutup cetakan yang rata lalu biarkan di dalam suhu 
kamar selama 2 jam. Total keseluruhan sampel ada 4 sampel dengan perbandingan fraksi volume serat dan matriksnya 5\%:95\%, 10\%:90\%, 20\%:80\% dan 30\%:70\%.

Kemudian material komposit dikeluarkan dari cetakan lalu dilakukan pemotongan dengan gerinda. Material komposit dipotong sesuai standar SNI 01-7201-2006 dengan ukuran 10 x $10 \mathrm{~cm}$ seperti pada Gambar 6 berjumlah total 4 sampel.
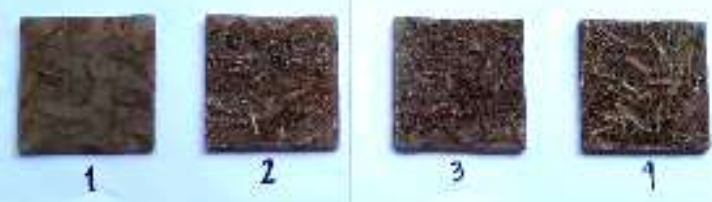

Gambar 6. Sampel 1. 2, 3, 4 material komposit

\subsection{Pengujian}

Pada penelitian ini dilakukan Uji Tarik pada material komposit. Uji tarik adalah salah satu pengujian yang dilakukan untuk mengetahui karakteristik dan sifat mekanik pada material khususnya kekuatan dan ketahanan pada beban tarik. Alat untuk melakukan uji tarik seperti pada Gambar 7.

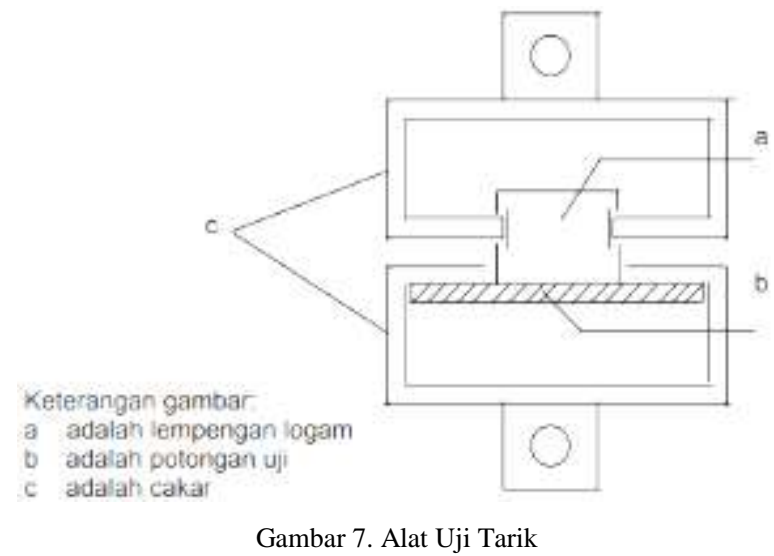

Sampel direkatkan pada lempengan logam yang berbentuk bujur sangkar pada bagian tengah, kemudian ditarik secara horizontal.

Setelah dilakukan pengujian tarik, dilakukan pengamatan pada struktur permukaan material komposit.

\section{Hasil dan Pembahasan}

Setelah dilakukan pengujian tarik berdasarkan standar SNI 01-7201-2006 tentang Kayu lapis dihasilkan dapat dilihat pada Gambar 8.

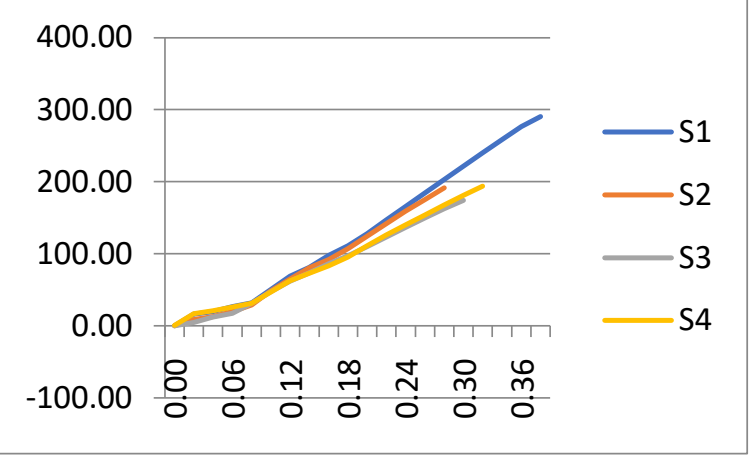

Gambar 8. Grafik force-dispalcement

Dari grafik pada Gambar 8 menunjukkan adanya kemiringan kurva daerah linier yang mengalami kecenderungan meningkat diiringi dengan bertambahnya fraksi volume serat jerami dari fraksi volume 5\%, 10\%, 20\% dan 30\%. Hal ini menunjukkan bahwa meningkatnya fraksi volume serat jerami pada material komposit mengakibatkan nilai modulus elastisitas semakin besar. Semakin besar nilai modulus elastisitas maka material sebut semakin kaku. Kekakuan ini terjadi karena adanya penambahan material serat jerami pada matriks nya [9].

Tabel 1. Tabel Uji Tarik Papan Komposit

\begin{tabular}{llll}
\hline Komposisi serat & Komposisi Resin & $\begin{array}{l}\text { Kekuatan } \\
(\mathrm{MPa})\end{array}$ & Tarik \\
\hline $5 \%$ & $95 \%$ & 9.67 \\
$10 \%$ & $90 \%$ & 6.38 \\
$20 \%$ & $80 \%$ & 5.81 \\
$30 \%$ & $70 \%$ & 6.45 \\
\hline
\end{tabular}

Pada Tabel 1 dapat dilihat bahwa kekuatan tarik material komposit serat jerami mengalami penurunan seiring bertambahnya fraksi volume serat jerami. Hal tersebut terjadi dikarenakan oleh ikatan yang kurang baik antara serat jerami dan matriksnya [9].

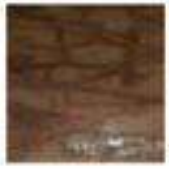

1

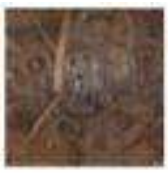

2

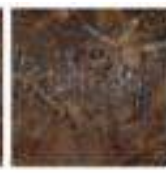

3

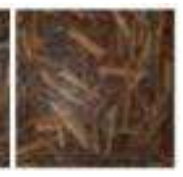

4
Gambar 9. Foto Struktur Permukaan Komposit

Pada Gambar 9 yang terdiri dari 4 sampel tersebut, terlihat adanya void atau gelembung udara pada ke 4 sampel tersebut. Namun, paling banyak terlihat pada sampel ke 2 dan 3. Adanya void pada material komposit kemungkinan terjadi akibat tidak merata nya penyebaran serat jerami. Material komposit yang terdapat void atau gelembung udara sangat berbahaya karena serat jerami tidak didukung oleh matriks apabila material komposit menerima beban, maka daerah tegangan akan berpindah ke daerah void 
sehingga akan menurunkan kekuatan material komposit tersebut seperti yang sudah dijelaskan di beberapa jurnal. Salah satunya penelitian Andi Saidah dkk pada tahun 2018 dengan judul pengaruh fraksi volume serat terhadap kekuatan mekanik komposit serat jerami padi epoxy dan serat jerami padi resin yukalac [9].

\section{Kesimpulan}

Dari peneletian ini dapat disumpulkan bahwa material komposit berserat jerami dan bermatriks polyester dapat dijadikan bahan alternatif pembuatan kayu lapis. Dengan nilai kekuatan tarik, 9.67 MPa, 6.38 MPa, 5.81 MPa, dan 6.45 MPa. Dari semua nilai kekuatan tarik tersebut memenuhi standar minimal dari kayu lapis dimana nilainya harus kurang dari $0.4 \mathrm{MPa}$. Walaupun semua sampel memenuhi standar minimal, dapat dilihat dari struktur permukaannya bahwa adanya gelembung atau void paling banyak pada sampel ke $2 \& 3$ yang berfraksi $10 \%$ serta $20 \%$. Untuk itu perlu diusahakan meminimalisir void agar ikatan yan terjadi antara serat dan matriks terjadi sempurna.

Untuk selanjutnya perlu dilakukan penelitian dengan pengujian seperti Uji Pukul dan Uji Amplas untuk memenuhi syarat lainnya pada kayu lapis berstandar SNI.

\section{Daftar Rujukan}

[1] Elvida Yosefi Suryandari, 2008. Jurnal Penelitian Sosial dan Ekonomi Kehutanan. Analisis Permintaan Kayu Bulat Industri Pengolahan Kayu, 5 (1), 15-26.

[2] Indra Mawardi., Hasrin Lubis., 2019. Proses Manufaktur Plastik Dan Komposit. Revision ed. Yogyakarta: Penerbit Andi.

[3] Issac M.Daniel.,Ori Ishai., 2006. Engineering Mechanics Of Composite Material. $3^{\text {rd }}$ ed. New York : Oxford University Press.

[4] Newkarma, 2020. Bahan Komposit : Arti, Cara Membuat, dan Aplikasi [Online] (Updated 18 May 2020)

Tersedia di : https//muh-amin.com/bahan-komposit-arti-caramembuat-dan-aplikasi/ [Accessed 8 July 2021]

[5] Dinas Pertanian, 2019. Pemanfaatan Jerami Padi Menjadi Kompos [Online] (Update 21 October 2019)

Tersedia di

https://distan.bulelengkab.go.id/informasi/detail/atikel/pemanfa atan-jerami-padi-menjadi-kompos-47 [Accessed 8 July 2021]

[6] Cecep NN, dkk, 2020. Jurnal Fakultas Teknik. Pengaruh Panjang Serat Jerami Terhadap Tegangan Tarik Pada Komposit Untuk Aplikasi Mobil Listrik, 1 (1), 5-8.

[7] Kuncoro Diharjo, 2006. Jurnal Teknik Mesin. Pengaruh Perlakuan Alkali Terhadap Sifat Tarik Bahan Komposit Serat Rami-Polyester, 8 (1), 8-13.

[8] Denny N., Andi Alvin, 2012. J@TI Undip. Desain Proses Pembentukkan Serat Bambu Sebagai Bahan Dasar Produk Industri Kreatif Berbahan Dasar Serat Pada UKM, VII (3), 139-142.

[9] Andi Saidah., dkk, 2018. Jurnal Konversi Energi dan Manufaktur UNJ. Pengaruh Fraksi Volume Serat Terhadap Kekuatan Mekanik Komposit Serat Jerami Padi Epoxy dan Serat Jerami Padi Resin Yukalac 157, 2, 96-101

[10]Emon Azriadi, 2018. JUTIN. Pemanfaatan Serat Jerami Sebagai Papan Matrix Composite (PMC), 1 (1), 91-95.

[11] Ahmad Fikri., dkk, 2020. Jurnal Fakultas Teknik. Pengaruh Masa Filler Composite Dari Serat Jerami Terhadap Nilai Tegangan Tarik Bahan Untuk Body Mobil Listrik, 1 (1), 1-4. 